\title{
Choosing Judges in Brazil: Reassessing Legal Transplants from the United States
}

Maria Angela de Santa Cruz Oliveira Jardim

Nuno Garoupa

ngaroup@gmu.edu

Follow this and additional works at: https://scholarship.law.tamu.edu/facscholar

Part of the Law Commons

\section{Recommended Citation}

Maria A. de Santa Cruz Oliveira Jardim \& Nuno Garoupa, Choosing Judges in Brazil: Reassessing Legal Transplants from the United States, 59 Am. J. Comp. L. 529 (2011).

Available at: https://scholarship.law.tamu.edu/facscholar/451

This Article is brought to you for free and open access by Texas A\&M Law Scholarship. It has been accepted for inclusion in Faculty Scholarship by an authorized administrator of Texas A\&M Law Scholarship. For more information, please contact aretteen@law.tamu.edu. 


\title{
MARIA ANGELA JARDIM DE SANTA CRUZ OLIVEIRA* AND NUNO GAROUPA**
}

\author{
Choosing Judges in Brazil: Reassessing Legal \\ Transplants from the United States***†
}

This Paper compares the Brazilian with the United States general procedures of judicial selection at the state and federal levels. The most significant difference between the two approaches is that in Brazil the selection at the lower level is entirely administered by the judiciary, while in the United States, judges are either approved by the executive or elected by popular vote. At the Supreme Court level, however, the Brazilian Constitution uses the same mechanism that is used in the United States, namely presidential nomination and Senate confirmation. This Article contends that the constitutional transplant of the U.S. model of judicial selection, at the Supreme Court level, has produced a marked balance of power between different branches of the Brazilian government and has led to significantly fewer conflicts between the president and the Senate than in the United States. We will try to explain why apparently identical legal institutions have evolved in such different ways, in particular focusing on the specific role of the Senate in confirming presidential nominees.

\section{INTRODUCTION}

The selection of judges has always been a difficult process, designed to develop and assure a fair and effective rule of law. The separation of power demands an independent judiciary. If institu-

* PhD candidate in international law at the Graduate Institute of International and Development Studies, Geneva, Switzerland; visiting researcher at Harvard Law School (2005); LL.M., Harvard Law School (2004); postgraduate studies in economic and corporate law, Fundação Getúlio Vargas (2003), Bachelor's degree in Law, Universidade de Brasília (1993).

** Professor of Law and H. Ross and Helen Workman Research Scholar, University of Illinois College of Law; LL.M. University of London (2005); PhD Economics, University of York (1998); M.Sc. Economics, University of London (1994); Bachelor's degree in Economics, Universidade Nova de Lisboa (1992).

*** The authors are grateful to Mathias Reimann and to an anonymous referee for their helpful suggestions. Carolina Arlota, Mariana Monjardim, Isabel Peres, Gustavo Ribeiro and Roya $H$. Samarghandi have provided excellent research assistance. The usual disclaimer applies.

$\dagger$ DOI 10.5131/AJCL.2010.0020 
tions are to function properly, the judiciary must be accountable, yet the requirements of independence and accountability push the structure of judicial institutions in opposite directions. ${ }^{1}$ Each legal system responds to this complex trade-off according to the needs of the country, its local peculiarities and the expectations of its people when it comes to dispute resolution. International pressure and globalization add new requirements to legal reforms addressing judicial independence and accountability.

Legal scholars have frequently distinguished between "career judges" and "recognition judges." 2 The career judiciary usually is part of the prevalent system in Europe and in civil law jurisdictions more generally, while the recognition judiciary is mostly associated with the United States and other common law jurisdictions.

A career judiciary is part of a system that includes the following features: (1) judges are initially appointed to junior positions either in trial courts or assisting senior judges; (2) judges are promoted to senior positions at later stages which may include positions on the supreme court; (3) tenure is not attached to a particular position but to the entire career; and (4) transfers to courts of equal seniority levels are generally allowed. ${ }^{3}$ Usually, the appointment mechanisms used in civil law jurisdictions largely insulate career judiciaries from political considerations. ${ }^{4}$

A recognition judiciary is part of a different system that tends to include the following features: (1) judges are selected after an initial career in a legal profession; (2) judges are not usually promoted; and (3) tenure is attached to a specific court (not always, but in many cases life tenure). A recognition judiciary tends to rely on appointment mechanisms that involve the other branches of government, and therefore are often more politicized in nature. ${ }^{5}$

Each system entails different characteristics. The precise design of each of the mechanisms for judicial appointment-assessment and removal-provides for a specific balance between external and internal audiences. ${ }^{6}$ Other aspects of the judicial system, including the possibility of separating opinions and dissents, sentencing and proce-

1. See Nuno Garoupa \& Tom Ginsburg, Guarding The Guardians: Judicial Councils and Judicial Independence, 57 AM. J. ComP. L. 103 (2009), and Nuno Garoupa \& Tom Ginsburg, The Comparative Law and Economics of Judicial Councils, 27 BERKELEY J. INT'L L. 52 (2009).

2. See, among others, Nicholas Georgakopoulos, Independence in the Career and Recognition Judiciary, 7 U. CH. L. Sch. RoundTaBle 205 (2000).

3. Id.

4. See Garoupa \& Ginsburg, Guarding the Guardians and Garoupa \& Ginsburg, The Comparative Law and Economics of Judicial Councils, supra note 1.

5. See Georgakopoulos, supra note 2.

6. See Nuno Garoupa \& Tom Ginsburg, Judicial Audiences and Reputation: Perspectives from Comparative Law, 47 Colum. J. Transnat'L L. 451 (2009), and Nuno Garoupa \& Tom Ginsburg, Reputation, Information, and the Organization of the Judiciary, 4 J. CoмP. L. 201 (2010). 
dural discretion, the scope of appeals (for example, de novo review), the use of citations, the court's powers to select cases, the management and budget of the court system, and the size of the courts enter into play. ${ }^{7}$ Not surprisingly, career and recognition judiciaries emerge in very different institutional settings.

It has been acknowledged that career and recognition judiciaries are generalist classifications. Recognition judiciaries in the federal courts in the United States are not identical with recognition judges in the United Kingdom. ${ }^{8}$ Many states in the United States elect their judges for fixed terms whereas the appointment mechanism to the federal courts involves nomination by the President and confirmation by the Senate.

Career judiciaries in Germany, France, Italy or Japan look similar in many regards but also show significant differences. ${ }^{9}$ For instance, the judges of constitutional courts in most civil law countries are more easily described as a recognition judiciary rather than a career judiciary. Finally, some career judiciaries may have more discretion (such as Germany) than some recognition judiciaries (such as the United Kingdom). ${ }^{10}$

Distinctions between career and recognition judiciaries are useful to identify general approaches to bringing about a balance between independence and accountability and to analyze particular incentives and institutional attributes. ${ }^{11}$ However, in order to understand the proper functioning of a particular judiciary, we cannot rely all too heavily on this particular classification because it is too broad and probably too divorced from the defining institutional factors. ${ }^{12}$

In this context, Brazil is an important and interesting example. Due to the Portuguese colonization and influence, Brazil is a civil law country, and codification occurred after independence (1822). ${ }^{13}$ As with most civil law jurisdictions, Brazil has a career judiciary for the

7. Id. For example, in Brazil, dissenting votes are allowed, dissenting opinions are published, and the judiciary manages the court system with an independent budget. In addition, courts' deliberations are open to the public. (1996).

8. See Richard A. Posner, Law and Legal Theory in the UK and the USA

9. From an outside, common law point of view they might look similar. However, there are significant differences. For example, in France or Italy, a powerful judicial council prevails while that is not the case in Germany or in Japan.

10. See Georgakopoulos, supra note 2.

11. See Richard A. Posner, What Do Judges and Justices Maximize? (The Same Thing as Everybody Else), 3 Sup. CT. Econ. REv. 1 (1993); Richard A. Posner, Judicial Behavior and Performance: An Economic Approach, 32 FLA. ST. U. L. Rev. 1259 (2005); and Richard A. Posner, How Judges Think (2008).

12. This happens in the same way that general references to the "common law system" or the "civil law system" can be problematic when addressing particular issues. See Ugo Mattei, Three Patterns of Law: Taxonomy and Change in the World's Legal Systems, 45 AM. J. CoMP. L. 45 (1997).

13. Under the 1824 Constitution, the Brazilian legislator was supposed to enact a civil code and a criminal code. The criminal code was enacted in 1830 and the code of 
first instance courts. Nevertheless, judges for higher courts include, other than the career judiciary, successful legal practitioners laterally entering late in their careers as well as senior law professors, as with the standard recognition judiciary. Indeed, it is more accurate to say that Brazil has a mixed system of judicial selection with components usually associated with civil law countries (career judiciary) as well as elements typically found in the common law systems (recognition judiciary). Whereas the career judiciary can be traced back to the civil law tradition related to the Portuguese colonization, the recognition judiciary at the Supreme Court level results directly from the influence of the U.S. Constitution in Brazil. ${ }^{14}$

Like the United States, Brazil is a federation with (twentyseven) state systems in addition to a federal system. This federal system, includes specialized courts: labor courts, electoral courts, and military courts. However, in contrast to the U.S. Constitution, the Brazilian Federal Constitution prescribes the methods of selection of judges not only in the federal judicial system, but also for state courts. Article 125 establishes expressly that the state judicial systems shall follow the principles of the Federal Constitution. ${ }^{15}$ Therefore, both state and federal judges are bound by the same general rules. As a result, the Brazilian judiciary, despite the separate federal and state jurisdictions, is regulated by a uniform rule that eliminates the significant differences we find in the United States.

At the top of the Brazilian court system is the Supreme Federal Court (Supremo Tribunal Federal), which is essentially responsible for safeguarding the Constitution, as stated in Article 102 of the Federal Constitution. ${ }^{16}$ The Supreme Federal Court (hereinafter "Supreme Court") is the court of last resort in constitutional matters. It has jurisdiction over the entire nation and may receive appeals against judgments rendered by the lower courts. The Supreme Court is also in charge of abstract constitutional review of federal and state

criminal procedure in 1832 . After several attempts, the civil code was finally enacted in 1916 (a new civil code has been enacted in 2002).

14. See Maria Angela Jardim de Santa Cruz Oliveira, Reforming the Brazilian Supreme Court: A Comparative Approach, 5 Wash. U. Global Stud. L. Rev. 99 (2006).

15. Article 125 of the Federal Constitution reads: "The states shall organize their judicial system, observing the principles established in this Constitution. (1) The competence of the courts shall be defined in the Constitution of the state, and the law of judicial organization shall be the initiative of the Court of Justice. (2) (. . .)."

16. Article $\mathbf{1 0 2}$ of the Federal Constitution reads:

The Supreme Federal Court is responsible, essentially, for safeguarding the Constitution, and it is within its competence: (. . .) III - to judge, on extraordinary appeal, cases decided in a sole or last instance, when the decision appealed: a) is contrary to a provision of this Constitution; b) declares a treaty or a federal law unconstitutional; $c$ ) considers valid a law or act of a local government contested in the light of this Constitution; d) considers valid local law contested in the light of federal law (. . .). 
laws a characteristic borrowed from the European model of constitutional adjudication. ${ }^{17}$

The composition and the appointment mechanism to the Brazilian Supreme Court follow closely the U.S. model, which is not surprising given the influence of the U.S. Constitution on the 1891 Brazilian Constitution. However, the direct transplant of the U.S. model of selection and appointment of justices has not reproduced the same institutional patterns. This Paper explains why the transplant of a particular appointment mechanism does not necessarily produce the same institutional outcome. Local determinants matter and shape the implementation of a particular transplant.

There are three plausible explanations for the different attitudes displayed by the U.S. and Brazilian Senates toward Supreme Court nominees:

(a) The stakes in appointing Supreme Court justices in Brazil are lower due to ideological and cultural differences between the two countries, such as fewer clashes between a partisan-oriented ideological majority and minority in Brazil;

(b) The balance of power between the states and the federal government as well as between the main political parties differs. For instance, since Brazil does not have a stable two-party system, and the Senate is not polarized and structured around a two-party tradition;

(c) Since there is a career judiciary in Brazil, a deferential Senate contributes to a more effective system of checks and balances between the federal government and this career judiciary; a less deferential Senate would inevitably reduce presidential influence in selecting judges and thereby empower the career judiciary.

These three elements are all of equal importance and explain why a transplant has evolved into a different institutional arrangement. ${ }^{18}$ Based on these explanations, the Article identifies interesting differences between the Brazilian and American political and legal systems.

We will start by explaining the methods of judge selection in Brazil in some detail. There are several methods, varying according to the kind of judgeship position involved. Depending on the level of the court, a specific method applies (summarized in Annexes 1 and 2).

17. The Supreme Federal Court also has original jurisdiction over various controversies, and appellate jurisdiction concerning political crimes and a few cases judged originally by the Superior Courts. A complete explanation of the Supreme Federal Court jurisdiction will not be presented here since it is not the focus of this Article. For further details on the Supreme Federal Court jurisdiction, see Oliveira, supra note 14 .

18. Other authors have focused on the party system. See, for example, Leany Barreiro Lemos \& Mariana Llanos, The Supreme Court Nominations in Brazil (19852010): Presidential or Coalitional Preferences?, mimeograph on file with the authors (2010). 
The second part of the paper discusses the influence of the American model on appointments to the Brazilian Supreme Court and the implications for current institutional arrangements. In particular, we assess the extent to which a legal transplant concerning rules of judicial appointment produces different outcomes depending on local determinants.

\section{Methods of Judicial Selection in Brazil}

In order to explain the methods of judicial selection, it is necessary to first briefly introduce the court system of Brazil. As mentioned above, at the federal level there are the courts of general (federal) jurisdiction as well as three specialized tribunals: labor, electoral and military courts. Each of them have trial courts, regional appellate courts, and one national court of last resort, known as "Superior Courts" (Tribunais Superiores) ${ }^{19}$ except for the military division, which has trial courts and one nationwide appellate court only. At the state level, each state has trial courts and one appellate court.

For practical purposes, we will divide the methods of selecting judges according to the judgeship level into four main categories: trial, appellate, superior courts and the Supreme Court.

\section{A. Trial Court Judgeships}

Article 93 of the Brazilian Constitution states the principles to be observed by the Statute of the Judicature (Estatuto da Magistratura), which, as mentioned earlier, applies to every judge in the country. ${ }^{20}$

19. The federal courts of general jurisdiction are divided among five regions; each region has many trial courts and one Federal Regional Court (appellate court). The labor courts are distributed among twenty-four regions and each of these regions includes various trial courts and one Regional Labor Court (appellate court). On the other hand, electoral courts are scattered over twenty- seven regions, and each of these regions comprises several electoral trial courts and one Regional Electoral Court (appellate court).

20. Article 93 of the Federal Constitution reads:

A supplementary law, proposed by the Supreme Federal Court, shall provide for the Statute of the Judicature, observing the following principles: I - admission into the career, with the initial post of substitute judge, by means of a civil service entrance examination of tests and presentation of academic and professional credentials, with the participation of the Brazilian Bar Association in all phases, it being required for the law bachelors a minimum of three years' experience in juridical activities, obeying the order of classification for appointments; II - promotion from level to level, based on seniority and merit alternately, observing the following rules: a) the promotion of a judge who has appeared in a merit list for three consecutive times or for five alternate times is mandatory; $b$ ) merit promotion requires two years in office in the respective level and that the judge should appear in the top fifth part of the seniority list of such level, unless no one satisfying such requirements is willing to accept the vacant post; c) appraisal of merit according to the criteria of promptness and reliability in the exercise of the jurisdictional function and according to attendance and achievement in official or recog- 
This Article states that one must pass an entry-level examination to be admitted to a judicial career. In other words, anyone interested in being a trial judge at the state or federal levels has to pass this exam. The tests are administered according to vacancy needs and are only open to applicants with a bachelor's degree in law and at least three years of professional legal experience.

The Brazilian career judiciary has its peculiarities when compared to the European model. In Brazil, candidates do not have to attend a special school for judges as a prerequisite to taking the entry exam. In addition, there is no compulsory long-term program of study at judicial training schools. To be sure, there are judicial training schools in the state and federal judiciaries, all of them work independently and some of them are private (not owned and managed by state or federal governments, but by judges' associations). But these judicial training schools provide short-term courses for new judges, as well as continued education for judges at any point in their careers. In the past few years, the National School of Judicial Training and Improvement (Escola Nacional de Formação e Aperfeiçoamento de Magistrados) was created to regulate, authorize and accredit courses for judges. ${ }^{21}$ Unlike in the French or the Italian models, there is a variety of training schools. ${ }^{22}$

The entry-level examination traditionally consists of three phases: written examinations oral examinations, and an evaluation of academic and professional credentials such as graduate studies, publications and years of work experience. In recent times, examinations for trial judgeships at both the state and the federal levels have included a fourth phase: a four-month course provided by the state and federal judicial training schools. ${ }^{23}$ The examination is run by the

nized improvement courses; $d$ ) in determining seniority, the court may only reject the judge with the longest service by the justified votes of two-thirds of its members, according to a specific procedure, ample defense being assured, the voting being repeated until the selection is determined; e) there shall not be promoted the judge who, without cause, retains case files longer than the time determined by law, it being forbidden to return them to the court without the proper sentence or other applicable action; III - access to the courts of second instance shall obey seniority and merit, alternately, as determined at the last or only level; (. . .).

21. Prescribed by Constitutional Amendment 45 of 2004, Article 105, sole paragraph, section I, the National School of Judicial Training and Improvement was created on November 30, 2006, under the Superior Court of Justice [Superior Tribunal de Justiça]. It should be noted that Constitutional Amendment 45 of 2004 also created a separate national school of judicial training for labor judges only.

22. There are twenty-nine state judicial schools, and five federal schools. See http://www.stj.jus.br/portal_stj/publicacao/engine.wsp?tmp.area $=792$ (last visited Mar. 16, 2010). Furthermore, every Brazilian state has a judicial school of electoral jurisdiction, except one. See http://www.tse.gov.br/eje/html/apresentacao.html (last visited Sept. 13,2010). In addition, there are judicial schools for labor judges only. See $\mathrm{http} / / / \mathrm{www}$. enamat.gov.br/?page_id=65 (last visited Sept. 13, 2010).

23. See Resolution n.1, 17 September 2007, issued by the National School of Judicial Training and Improvement (Escola Nacional de Formação e Aperfeiçoamento de 
appellate court that has jurisdiction over the vacant positions for trial judgeships, through a board of examiners. The Brazilian Bar Association participates in this selection process by appointing a lawyer of its choice to the examination board.

After passing the entrance test, the candidates will take office in order of classification; in other words, candidates who obtain the highest scores are hired first. These newly-admitted judges then receive the title of "substitute judge" (juiz substituto), the entry-level position. ${ }^{24}$ It is important to note that a substitute judge has the same duties and responsibilities as a senior trial judge. After two years in office, trial judges acquire life tenure ${ }^{25}$ and serve to the mandatory retirement age of seventy.

The electoral courts have a special structure. The electoral judicial system has jurisdiction over controversies arising out of election processes and is responsible for running elections in Brazil. This entails duties ranging from keeping registration lists to organizing the poll sites, as well as certifying election results and announcing the winners. Therefore, electoral court judgeships are not filled by an entry-level examination. They are comprised of state judges, experienced lawyers, and public prosecutors who undertake their electoral function in conjunction with their primary job for a two-year term; one consecutive term is permitted.

\section{B. Appellate Court Judgeships}

The Brazilian Constitution provides general rules of access to appellate courts. In general, judges of first instance fill appellate court seats. The appellate courts themselves select these first instance judges through an alternate criterion of seniority and merit. This means that if the previous appellate judge was selected by seniority, the next will be exclusively chosen by merit, and vice-versa.

When the selection is based on seniority, the appellate court may reject the most senior judge only by a reasoned two-thirds vote of its members; the candidates are allowed fully to defend themselves against the arguments made against their promotion. Elevation based on merit considers a judge's performance and reliability in the exercise of his or her judicial functions as well as attendance in accredited or official advanced legal education courses. Article 93,

Magistrados), and Resolution n.41, 19 December 2009, issued by the Council of Federal Justice (Conselho da Justiça Federal). This course consists of a total of 480 hours, spread over four months (an average of a six-hour class per work day).

24. "Substitute judges" usually circulate throughout several districts and different specialized trial courts, and substitute for senior judges during their vacations or leaves, or help overburdened judges.

25 . During the first two years in office of entry-level judges, the respective appellate court may discharge "substitute" judges. After this period, judges may only be dismissed by a judicial decision, res judicata. 
section II, subpart $b$, of the Brazilian Constitution prescribes that merit-based promotion requires two years in office at the respective level and that the judge should be in the top fifth of the seniority list of such level, unless no one satisfying these requirements is willing to accept the vacant post. ${ }^{26}$ The promotion of a judge who entered a merit list three consecutive times or five non-consecutive times is mandatory.

Whenever possible, federal appellate court judges are selected in their respective region. They must be Brazilian nationals between the ages of thirty to sixty-five at the time of their appointment. As mentioned, career federal judges who are promoted by seniority or merit occupy the majority of seats in the federal regional courts. However, the Brazilian Constitution reserves one-fifth of the federal appellate court seats for members of the Brazilian Bar Association as well as members of the Public Prosecution, to be chosen by the President of Brazil (quinto constitucional). These seats are distributed alternately to knowledgeable and reputable lawyers with more than ten years of law practice and to members of the Federal Public Prosecution with over ten years of service. In other words, if the previous appellate judge was selected from a pool of lawyers, the next will be chosen from a pool of federal public prosecutors.

Executive choice is very restricted at the federal appellate courts, however. Either the bar association or the public prosecution's office, depending on whose turn it is to fill the appellate judgeship, conducts an internal selection process and then provides a list of six qualified members to the appellate court. The federal appellate court (Tribunal Regional Federal) then nominates three out of the six candidates suggested and submits them to the President of Brazil who has twenty days to select any of the three to fill the appellate judgeship position.

The state appellate courts (Tribunais de Justiça) follow the same process as for selecting federal appellate judgeships: four-fifths of the seats are filled by judges of first instance, the remaining fifth by lawyers and state public prosecutors. However, at the state level, the state governor, rather than the President of Brazil, chooses one-fifth of the seats from a list of three nominees presented by the state appellate court, selected from six candidates provided by either the bar association or state public prosecution.

Electoral appellate courts have a different judicial selection process because of their special duties of regulating the federal, state and municipal elections. There is one electoral appellate court (Tribunal Regional Eleitoral) in each state of Brazil. Electoral appellate courts have a mixed composition of lawyers, as well as state and federal judges, each with a two year-mandate that only permits one

26. See Lemos \& Llamos, supra note 18. 
consecutive term. Electoral appellate courts comprise seven judgeship positions. Two of these positions are set aside for state trial judges, and two for state appellate judges; all of these positions are filled by secret ballot among state appellate court judges. Another seat is reserved for a federal appellate judge of general jurisdiction. If a state capital does not have a federal appellate court, a federal trial judge may be appointed to the seat. Even in this case, the federal appellate court of that specific region makes the appointment. The President of Brazil fills the last two judgeships by picking from six knowledgeable lawyers of good moral standing nominated by the state appellate court.

As demonstrated, even though there is an executive role in the appointment to appellate court judgeships, it is not dominant, and the executive follows a complex process involving several government actors.

\section{Superior Courts Judgeships}

"Superior Courts" is a general term for national courts of last resort regarding several subject matter jurisdictions that do not involve constitutional issues: the Superior Court of Justice, the Superior Labor Court, the Superior Electoral Court, and the Superior Military Court. Each of these courts has a specific method for selecting its judges, and each of these methods is independently analyzed in the following section.

\section{The Superior Court of Justice}

Except for issues related to the specialized federal courts divisions, the Superior Court of Justice (Superior Tribunal de Justiça) is the court of last resort for federal law appeals from the federal appellate courts of general jurisdiction and from state courts, among other functions assigned by Article 105 of the Brazilian Constitution. ${ }^{27}$ Currently, it is composed of thirty-three seats.

27. Article 105 of the Federal Constitution reads:

The Superior Court of Justice has the competence to: I - institute legal proceeding and trial, in the first instance, of: a) in common crimes, the Governors of the states and of the Federal District, and, in such crimes and in crimes of malversation, the judges of the Courts of Justice of the states and of the Federal District, the members of the Courts of Accounts of the states and of the Federal District, those of the Federal Regional Courts, of the Regional Electoral and Labor Courts, the members of Councils or Courts of Accounts of the municipalities and the members of the Public Prosecution of the Union who act before court; b) writs of mandamus and habeas data against an act of a Minister of State, or Commander of the Navy, the Army or the Air Force, or of the Court itself; c) habeas corpus, when the constraining party or the petitioner is any of the persons mentioned in subitem a, or when the constraining party is a Minister of State, or Commander of the Navy, the Army or the Air Force, except for the competence of the Electoral Courts; d) conflicts of competence between any courts, except as provided in article 102, 
The judges of the Superior Court of Justice are appointed by the President of Brazil from reputable, knowledgeable Brazilian citizens between the ages of thirty-five and sixty-five years of age. After the executive choice is made, the presidential nominee must be confirmed by an absolute majority in the Senate.

Similar to the appellate court level, presidential leverage in making appointments is very limited. One-third of seats are reserved for judges of federal appellate courts of general jurisdiction and onethird for state appellate judges. For these two categories of seats, the Superior Court of Justice itself prepares a list of three nominees for the President of Brazil to choose from. The remaining one-third of seats is filled alternately by lawyers and both federal and state public prosecutors, who are chosen through procedures and requirements similar to those for the appellate courts. In other words, the Superior Court of Justice distills a list of three nominees from six candidates suggested either by the Brazilian Bar Association or by the public prosecution, depending on which organization's turn it is. This list is then presented to the President of Brazil so that he may select one of the three nominees. As mentioned earlier, the President's choice is subject to confirmation by the Senate.

\section{The Superior Labor Court}

The Superior Labor Court (Tribunal Superior do Trabalho) is the court of last resort for appeals arising under labor law. It is composed

I, 0 , as well as between a court and the judges not subject to it and between judges subject to different courts; e) criminal review of and the rescissory actions against its decisions; f) claims for the preservation of its competence and guarantee of the authority of its decisions; $g$ ) conflicts of duties between administrative and judicial authorities of the Union, or between judicial authorities of one state and administrative authorities of another or of the Federal District, or between those of the latter and those of the Union; $h$ ) writs of injunction, when the drawing up of a regulation is the responsibility of a federal body, entity, or authority, of the direct or indirect administration with the exception of the cases within the competence of the Supreme Federal Court and of the bodies of the Military Justice, of the Electoral Justice, of the Labor Justice and of the Federal Justice. i) the homologation of foreigner sentences and the granting of exequatur to rogatory letters; II - judge, on ordinary appeal: a) habeas corpus decided in a sole or last instance by the Federal Regional Courts or by the courts of the states, of the Federal District and the Territories, in the event of a denial; b) writs of mandamus decided in a sole instance by the Federal Regional Courts or by the courts of the states, of the Federal District and the Territories, in the event of a denial; c) cases in which the parties are a foreign state or international organization, on the one part, and a municipality or a person residing or domiciled in the country, on the other part; III - judge, on special appeal, the cases decided, in a sole or last instance, by the Federal Regional Courts or by the courts of the states, of the Federal District and the Territories, when the decision appealed: a) is contrary to a treaty or a federal law, or denies it effectiveness; b) considers valid an act of a local government contested in the light of a federal law; c) confers upon a federal law an interpretation different from that which has been conferred upon it by another court (. . .). 
of twenty-seven judges who are chosen from Brazilian citizens between the ages of thirty-five and sixty-five. One-fifth of the seats are alternately reserved for lawyers with more than ten years of practice in law and labor public prosecutors with more than ten years of work experience. All other judgeships are reserved for career labor judges.

The President of Brazil appoints all judges to this Court. Here again, presidential choice is very narrow. Following the same procedures of the Superior Court of Justice, the Superior Labor Court presents three career judges to the President, who chooses one candidate to fill one seat reserved for career judges. As for the remaining one-fifth of seats earmarked for lawyers and prosecutors, the Superior Labor Court prepares a list of three nominees out of six candidates suggested either by the Brazilian Bar Association or by the labor prosecution, depending on which organization's turn it is. This list is then presented to the President of Brazil, who may choose one of the three nominees. Again, all appointments made by the President require confirmation by the Senate.

\section{The Superior Electoral Court}

Along the lines of the electoral appellate courts, the Superior Electoral Court (Tribunal Superior Eleitoral) has a diverse composition of seven members serving for a two-year period, with one consecutive term allowed. Three of the seats on this Court are reserved for Supreme Court justices, who are chosen by secret ballot conducted among the Supreme Court Justices. As a customary rule, the Supreme Federal Court elects its members to the Superior Electoral Court according to seniority. In addition, two seats are filled by members of the Superior Court of Justice, also selected by secret vote by the Superior Court of Justice. Lastly, the President of Brazil appoints two lawyers from six knowledgeable candidates with flawless conduct who were selected by the Supreme Court.

\section{The Superior Military Court}

The Superior Military Court (Superior Tribunal Militar) is a federal court of national jurisdiction on military crimes. In contrast to the other Brazilian judicial systems, federal military courts do not have the classical division into trial, appellate, and superior courts. Instead, they have trial courts and one superior court only. Four military officers and one non-military career judge compose the military trial courts. These non-military career judges are recruited by public examination as described above.

Among other functions, the Superior Military Court has jurisdiction over appeals against military trial courts, as well as jurisdiction over cases involving crimes committed by high-ranking military officers. It is composed of fifteen judges, five of whom are civilians. 
Superior Military Court judges are freely appointed by the President of Brazil among Brazilian citizens over the age of thirty-five, in the following categories: three seats are set aside for Admirals of the Navy; four seats go to Generals of the Army; three seats to Generals of the Air Force; three seats to knowledgeable lawyers with flawless conduct and more than ten years of practice; and, finally, two seats to trial court judges ${ }^{28}$ and public prosecutors.

\section{The Supreme Court}

As previously mentioned, the Supreme Court is the highest court of Brazil. It is composed of eleven justices. Like the U.S. model, ${ }^{29}$ the constitutional authority for the appointment of Supreme Court justices rests with the President of Brazil, subject to Senate confirmation by absolute majority. The Supreme Court appointment process is unique in that it does not set aside seats for any specific category of legal professionals. It does require nominees to be knowledgeable in law, have a flawless reputation, and be in a specific age range-between thirty-five and sixty-five. Even so, it is in the appointment of Supreme Court seats that the executive has the greatest leverage. However, judicial self-government guaranteed in Article 96, I of the Federal Constitution grants the justices of the Supreme Court the prerogative of electing, among themselves, the President and Vice-President of the Court. ${ }^{30}$ As a customary rule, the Supreme Court justices rotate as President and Vice-President, for a two-year term, in order of seniority. ${ }^{31}$

Brazil adopted the appointment process of the U.S. Constitution in 1891. There have been passionate debates about the discretionary power of the President of Brazil to appoint Supreme Court justices. ${ }^{32}$

28. The Superior Military Court's seats reserved for first instance judges refer to non-military career judges only.

29. See Norman Dorsen, The Selection of U.S. Supreme Court Justices, 4 INT'L J. CoNST. L. 652 (2006).

30. Article 96 of the Federal Constitution reads,

It is of the exclusive competence of: I - the courts: a) to elect their directive bodies and to draw up their internal regulations, in compliance with the rules of proceedings and the procedural guarantees of the parties, and regulating the competence and the operation of the respective jurisdictional and administrative bodies; (b) (. . .).

31. One possible consequence of this rule of frequent rotation is to insulate the President and the Vice-President of the Court from political pressure. Historically, however, this rule was introduced in 1890 and the reason might have been to avoid excessive concentration of power and internal rivalries.

32. Newton Tavares Filho, Democratização do Processo de Nomeação dos Ministros do Supremo Tribunal Federal [Nomination Process of Justices of the Federal Supreme Court], Consultoria Legislativa da Câmara dos Deputados (2006), available at http://bd.camara.gov.br/bd/bitstream/handle/bdcamara/1596/democratizacao processo_tavares.pdf?sequence $=1$ (last visited Mar. 13, 2010); Hélio Bicudo, Nomeações para o Supremo Tribunal Federal [Nominations to the Federal Supreme Court], Sept. 21, 2009, available at http://helio-bicudo.blogspot.com/2009/09/nomea 
Furthermore, the Brazilian Supreme Court appointment process has lately been under severe scrutiny because of a massive reconfiguration of the composition of the Court. It came as a result of seven justices reaching the mandatory retirement age, the voluntary retirement of two more justices, and the death of another, all within a nineyear period. With one exception, all of these losses occurred during President Lula's terms of office. ${ }^{33}$

The fact that one single President nominated more than half of the Supreme Court justices brought a lot of attention to the selection process and the future of the Supreme Court. We must note, however, that the important changes in the composition of the Supreme Court under President Lula may be attributed to an unusual combination of circumstances. Indeed, previous Presidents were not so lucky. ${ }^{34}$

In addition, Senate confirmation is required for Supreme Court appointments. The Senate has refused to confirm five presidential nominees at the end of the nineteenth century during President

coes-para-o-supremo-tribunal.html (last visited Mar. 13, 2010); Jurista critica sabatinas de indicados ao STF [Jurist criticizes public hearings of STF nominees], O Estado de São Paulo, Sept. 28, 2009, available at http://www.estadao.com.br/noticias/ nacional,jurista-critica-sabatinas-de-indicados-ao-stf,442224,0.htm (last visited Mar. 13,2010 ).

33. President Lula took office in 2003 for a four-year mandate and was subsequently reelected for a second term, which ended in December 2010. President Lula appointed six of the current Justices of the Supreme Court and he left to his successor, newly-elected President Dilma Rousseff, one vacant seat to be filled due to the mandatory retirement age of Justice Eros Grau in August 2010. See table below for details:

\begin{tabular}{|l|c|c|c|}
\hline \multicolumn{1}{|c|}{ Justice } & $\begin{array}{c}\text { Period in } \\
\text { Office }\end{array}$ & $\begin{array}{c}\text { Date of } \\
\text { Retirement }\end{array}$ & Reason \\
\hline Néri da Silveira & $1981-2002$ & Apr 24, 2002 & Mandatory retirement \\
\hline Moreira Alves & $1975-2003$ & Apr 22, 2003 & Mandatory retirement \\
\hline Sydney Sanches & $1984-2003$ & Apr 25, 2003 & Mandatory retirement \\
\hline Ilmar Galvão & $1991-2003$ & May 3,2003 & Mandatory retirement \\
\hline Maurício Corrêa & $1994-2004$ & May 8,2004 & Mandatory retirement \\
\hline Carlos Velloso & $1990-2006$ & Jan 19, 2006 & Mandatory retirement \\
\hline Nelson Jobim & $1997-2006$ & Mar 29, 2006 & Voluntary retirement \\
\hline Sepúlveda Pertence & $1989-2007$ & Aug 17, 2007 & Voluntary retirement $*$ ) \\
\hline Menezes Direito & $2007-2009$ & Sep 1,2009 & Death \\
\hline Eros Grau & $2004-2010$ & Aug 19,2010 & Mandatory retirement \\
\hline
\end{tabular}

(*) Although this is technically a voluntary retirement, Justice Sepúlveda Pertence retired only three months before he reached the mandatory retirement age of seventy years old, which was, in fact, a consequence of the imminent age limit.

34. President Lula's eight appointments thus far exceed the five appointments by President Sarney (1985-1990), four appointments by President Collor (1990-1992), one single appointment by President Itamar Franco (1992-1995), and three appointments by President Fernando Henrique Cardoso (1995-2003). In fact, one has to go back to the military regime to find larger numbers, such as eight appointments made by President Castelo Branco (1964-1967), seven appointments by President Ernesto Geisel (1974-1979), and nine appointments by President João Figueiredo (1979-1985). 
Floriano Peixoto's ${ }^{35}$ term (1891 to 1894$){ }^{36}$ At that time, the Senate confirmation sessions were held behind closed doors and the Senate only occasionally released the vote. ${ }^{37}$ After these initial setbacks, a President never saw a nominee rejected by the Senate.

In the period after the proclamation of the Brazilian Republic in $1889,{ }^{38}$ the Republican Constitution of 1891 replaced the first Brazilian Constitution of 1824, which was enacted during the Empire period (1822-1889). ${ }^{39}$ Although heavily influenced by the American Constitution, it also aimed to provide effective solutions to the problems that the U.S. Supreme Court had encountered, such as the

35. President Floriano Peixoto was elected Vice-President in $\mathbf{1 8 9 1}$ and replaced President Deodoro da Fonseca after his resignation in November 1891. He was the second Brazilian President after the fall of the Empire in 1889. President Peixoto finished his term in November 1894. He was not a popular president and had several political skirmishes with the Senate, including some over judicial appointments.

36. See José Celso De Mello Filho, Notas sobre o Supremo Tribunal (Império e República) [Notes on the Federal Supreme Court (Empire and REPUBLIC)], at 17 (2007).

37. See details in the following table based on Maria Angela Jardim de Santa Cruz Oliveira, Sobre a Recusa de Nomeações para o Supremo Tribunal Federal pelo Senado [About the Refusal of Nominations to the Federal Supreme Court by the Senate], 25 Revista de Direito Público 68 (2009):

\begin{tabular}{|c|c|c|c|}
\hline Justice & Nomination & $\begin{array}{c}\text { Senate Vote } \\
\text { (Favor-Against) }\end{array}$ & $\begin{array}{c}\text { Main Argument Against } \\
\text { Nomination }\end{array}$ \\
\hline Cândido Barata Ribeiro & Oct 1893 & $\begin{array}{c}4-27 \\
\text { (Sept 1894) }\end{array}$ & $\begin{array}{c}\text { No law degree } \\
\text { (i) }\end{array}$ \\
\hline $\begin{array}{c}\text { Antônio Caetano Seve } \\
\text { Navarro }\end{array}$ & Sept 1894 & (Oct 1894) & $\begin{array}{c}\text { Probably political } \\
\text { (ii) }\end{array}$ \\
\hline $\begin{array}{c}\text { Innocencio Galvão de } \\
\text { Queiroz }\end{array}$ & Sept 1894 & (Oct 1894) & $\begin{array}{c}\text { Not enough knowledge } \\
\text { about the law } \\
\text { (iii) }\end{array}$ \\
\hline $\begin{array}{c}\text { Francisco Raymundo } \\
\text { Ewerton Quadros }\end{array}$ & Oct 1894 & (Nov 1894) & $\begin{array}{c}\text { No law degree } \\
\text { (iv) }\end{array}$ \\
\hline $\begin{array}{c}\text { Demosthenes da } \\
\text { Silveira Lobo }\end{array}$ & Oct 1894 & $\begin{array}{c}17-19 \\
\text { (Nov 1894) }\end{array}$ & $\begin{array}{c}\text { Probably political } \\
\text { (v) }\end{array}$ \\
\hline
\end{tabular}

(i) Although being an experienced politician, the nominee was a medical doctor, which was considered insufficient by the Senate to satisfy the constitutional requirement of having knowledge about the law. In fact, the constitutional requirement in 1891 generally required "having knowledge" but the Senate interpreted the requirement to be "having knowledge about the law."

(ii) The nominee was a Brazilian attorney with previous experience as state prosecutor, lawyer, local judge and state congressman. He had represented the state of Rio Grande do Sul in the lower house at the end of the Empire, 1886-1889.

(iii) Although the nominee had a bachelor's degree in law, he was also a general of the Brazilian Army.

(iv) The nominee was a general, later a field marshal (July 1895). He had a bachelor's degree in engineering, physics and mathematics.

(v) The nominee was the Postmaster General.

38. Brazil became independent from Portugal in 1822 when the Empire of Brazil was established.

39. The imperial Constitution of 1824 established the "Supreme Court of Justice" as the highest court in Brazil. The judicial nominations for this court did not require the Senate's approval. See De Mello FilHo, supra note 36, at 17. 
constant change of the number of justices allowed on the Court ${ }^{40}$ and Congress' constant limitation of the Court's jurisdiction. ${ }^{41}$ The fluctuations in these reflected the political evolution from the early Republic to the end of the nineteenth century at which point the role of the Supreme Court was pretty much settled. Obviously the Brazilian authorities did not want to repeat the entire historical process a century later. Therefore, the Constitution of 1891 expressly established the Brazilian Supreme Court's composition of fifteen justices, and explicitly described and defined the Court's jurisdiction. ${ }^{42}$

Nonetheless, the 1930 Revolution reduced the Supreme Court's composition to eleven justices by Decree 19656 of 1931 , issued by the Chief of the Provisional Government. At that occasion, six Supreme Court justices were forced to retire from their judicial functions. ${ }^{43}$ The eleven-justice composition was then maintained by the subsequent Constitutions of $1934^{44}$ and $1937,{ }^{45}$ both of which included the possibility of an increase of seats up to sixteen if proposed by the Supreme Court.

The Constitution of 1934 was enacted by a National Constituent Assembly to reestablish the democratic order. However, a coup d'état occurred three years later and, soon after, the Constitution of 1937 was enacted to strengthen the powers of the executive. During these periods (1930-1934 and 1937-1946), twenty-one justices were nominated to the Supreme Court without passing the Senate's scrutiny, although the constitutional form of selection of justices of the Supreme Court required Senate approval. ${ }^{46}$ As the dictatorship ended, the democratic Constitution of 1946 maintained the same selection process and number of seats on the Supreme Court.

Another coup d'état occurred in 1964. The number of seats on the Supreme Court was augmented to sixteen by Institutional Act number 2 of 1965, which was subsequently reaffirmed by the Constitution of 1967. However, in 1969 three Supreme Court justices were forced to retire. ${ }^{47}$ These positions were never filled because the Institutional

40. For example, the Judiciary Act of 1789, Judiciary Act of 1801, Repeal Act of 1802, Judiciary Act of 1807 , Judiciary Act of 1837, Judiciary Act of 1863, Judiciary Act of 1866, Judiciary Act of 1867, Judiciary Act of 1869.

41. Ex parte McCardle, 74 U.S. 506 (1869).

42. See Rui Barbosa, O Supremo Tribunal na Constituição Brasileira [The Federal Supreme Court in the Brazilian Constitution], 2 Revista do SuPREMo TribunaL 393 , at 395-96 (1914).

43. The following Justices were subject to compulsory retirement by Decree 19711 of 1931, a discretionary act of the Chief of the Provisional Government: Godofredo Cunha, Muniz Barreto, Pires e Albuquerque, Pedro Mibieli, Pedro dos Santos, and Geminiano da Franca.

44. Constitution of 1934, Article 73, sole paragraph.

45. Constitution of 1937, Article 97, sole paragraph and Article 98

46. See De Mello Fulho, supra note 36 , at 16.

47. Evandro Lins e Silva, Hermes Lima and Victor Nunes Leal were subject to compulsory retirement from the Supreme Court by Decree of January 16, 1969; they were essentially deposed by the military dictatorship. 
Amendment number $6^{48}$ of 1969 reduced the number of seats on the Supreme Court to eleven. Constitutional Amendment 1 of 1969 affirmed the composition of the Supreme Court with eleven members.

With democratization, the Constitution of 1988 preserved the composition of the Supreme Court and introduced a requirement that the Senate must hold a public hearing about the nominee at which he or she is present and asked questions by the senators. ${ }^{49}$ The Senate Committee on Constitution, Justice and Citizenship (Comissão de Constituição, Justiça e Cidadania) conducts this hearing and votes by secret ballot whether or not to recommend the nominee to the full Senate. The full Senate votes by secret ballot on whether or not to confirm the nominee.

Table one summarizes the changes in the composition of the Brazilian Supreme Court since independence in 1822.

Table One: Seats of the Supreme Court since INDEPENDENCE $(1822)^{50}$

\begin{tabular}{|l|l|}
\hline Imperial Constitution of 1824 & 17 \\
\hline Federal Constitution of 1891 & 15 \\
\hline Decree n. 19.656 of 1931 & 11 \\
\hline Federal Constitution of 1934 & 11 \\
\hline Federal Constitution of 1937 & 11 \\
\hline Federal Constitution of 1946 & 11 \\
\hline Institutional Act n. 2 of 1965 & 16 \\
\hline Federal Constitution of 1967 & 16 \\
\hline Institutional Act n. 6 of 1969 & 11 \\
\hline Federal Constitution of 1969 & 11 \\
\hline Federal Constitution of 1988 & 11 \\
\hline
\end{tabular}

III. Similarities and Differences between the Brazilian and U.S. MODELS

\section{A. General Analysis}

It is clear that overall, the judicial selection in Brazil is significantly different from the American system. Generally speaking, U.S. federal judges are nominated by the President and confirmed by the Senate, while state judges are usually selected by gubernatorial ap-

48. Article 1 of Institutional Act number 6, issued on February 1, 1969.

49. Constitution of 1988 , Article 52, III.

50. See De Mello Filho, supra note 36 , at 8. 
pointment, commission nomination (the so-called merit commission) or popular election. 51 The Brazilian court system has national features, with courts of heterogenous composition, where both federal and state judge selections are bound by the same principles; as a result, the process of judicial appointment is the same for both federal and state jurisdictions.

The most striking difference between judicial selection in Brazil and the United States is that, at the trial level, the Brazilian process of selecting judges is entirely administered by the judiciary, with no executive participation whatsoever. At the appellate level, the executive only appoints one-fifth of the seats and, as indicated earlier, there are very few candidates that the executive can choose from. The judiciary itself appoints all of the remaining appellate court seats.

At the Superior Courts, the judiciary's involvement is still powerful even though executive participation increases. Even at this level, presidential appointments are limited to short-listed candidates provided by the Superior Courts themselves, except for the Superior Military Court appointments, where the President freely selects the judges under certain categories.

Similar to the United States, in Brazil the most important executive role in the process of selecting judges is at the Supreme Court level. Needless to say, the Supreme Court appointments are the most controversial nominations because it is the highest court of the nation. Article II, section 2 of the U.S. Constitution prescribes that the President shall nominate and, by and with the advice and consent of the Senate, shall appoint judges to the Supreme Court. Over time, the American Senate has refused to confirm almost a quarter of the presidential nominations. ${ }^{52}$

The system of Supreme Court appointment in Brazil is a straightforward legal transplant of the American model. The Brazilian Senate has barred five confirmations in the beginning of the Brazilian Republic, proclaimed in $1889,{ }^{53}$ while the United States Senate has rejected twelve nominees from 1789 to $2010 .{ }^{54}$ Although

51. See Charles F. Abernathy, Law in the United States: Cases and Materials (1995); Federal Judiclal Center, The U.S. Legal System: A Short Description (2005), available at http://www.fjc.gov/public/pdf.nsf/lookup/ijr00003.pdf $/ \$$ file/ijr0000 3.pdf (last visited Jan. 10, 2010).

52. See Norman Dorsen et al., Comparative Constitutionalism: Cases and Materials (2003), and Charles Gardner Geyh, When Courts and Congress Collide: The Struggle for Control of America's Judicial System (2008). The Senate has barred twenty-eight appointments (out of one hundred and fifty-one presidential nominations). However, only twelve nominees were actually voted down. Others withdrew or were subject to filibuster.

53. See Oliveira, supra note 37.

54. The most recent defeat was that of Robert Bork in October 1987 who was perceived as too conservative by a large majority of the Senate (forty-two in favor and fifty-eight against). In addition, many of the recent confirmations were not unanimous and largely polarized. For example, consider the recent nominations of Justices 
statistically these numbers are not very different, the Brazilian senatorial rejections were concentrated in 1894 while the American Senate has exercised the right not to confirm episodically but throughout the entire period. Such trends reflect the fact that the Brazilian Senate, unlike its United States counterpart, has not been very obstinate concerning presidential nominations to the Supreme Court. In short, the two Senates show a rather different degree of deference toward the President, although the systems are similar.

There is yet another difference: the profiles of the Brazilian presidential choices contrast with the American ones. For instance, among the seven most junior justices in Brazil, only two are career judges and another came from a state appellate court to which he was appointed from the bar (seat earmarked for lawyers). This is quite different from the U.S. Supreme Court, where all current justices, except one, have had very extensive experience on the federal appellate courts. 55

\section{B. Focusing on the Supreme Court}

Throughout the twentieth and twenty-first centuries, the Brazilian system has thus not reproduced the same institutional features as the American model. Differently from the U.S. system-where "the Senate has by no means rubber-stamped presidential nominations" and presidents withdraw candidates when it is clear that the Senate will not confirm them ${ }^{56}$ - there exists a general feeling in Brazil that the Senate is largely deferential to the presidential choices and avoids opposing presidential choices for political reasons. This is reflected in the fact that no presidential nominee in Brazil has been forced to withdraw or has been formally rejected by the Senate since the end of the military dictatorship.

Several practical reasons explain why the Brazilian Senate has not exercised a strong interventionist power during the confirmation process. ${ }^{57}$ The most obvious explanation is that the president's party

Alito (2006, fifty-eight in favor and forty-two against), Sotomayor (2009, sixty-eight in favor and thirty-one against), Kagan (2010, sixty-three in favor and thirty-seven against) and Chief Justice Roberts (2005, seventy-eight in favor and twenty-two against).

55. More generally about the U.S. Justices, see David A. Yalof, PURsuit of JusTICES (1999). Justice Elena Kagan is an exception in this respect, a point mentioned by those opposing her confirmation by the United States Senate.

56. See Dorsen et AL., supra note 52, or Paul A. Freund, Appointment of Justices: Some Historical Perspectives, 101 HaRv. L. Rev. 1146 (1988). For example, the case of Harriet Miers nominated and withdrawn by President George W. Bush in 2005. For details on the nomination of Harriet Miers, see Jan CrawFord Greenburg, SUPREME Conflict: The Inside Story of the Struggle for the Control of the UntTed States Supreme Court (2007).

57. On the interventionist role of the U.S. Senate and the role played by the President, see, among others, Henry J. Abraham, Justices and Presidents: A Political History of Appointments to the Supreme Court (1992) and Henry J. Abraham, 
is usually able to achieve a majority in the Senate by forming coalitions with other parties. While in the United States there are only two political relevant parties, Brazil has many parties and that the president's coalition party usually faces only a minority opposition in the Senate. In cases where the nominations are highly controversial, presidents make concessions to opposing senators in their interest areas, therefore reaching political compromises that regularly produce a successful, although contentious, confirmation.

In the course of judicial reform talks in Brazil over the past few years, there were a few amendment proposals to change the method of selecting Supreme Court justices but none have been seriously considered thus far. Discussion regarding the judicial selection process for Supreme Court justices arises every time there is a vacant seat on the court. While proposals for constitutional amendments have been presented in Congress, there is still no consensus as to what should be reformed. Table two summarizes the appointments to the Court since the 1988 Constitution. We chose to focus on the last twentythree years since democracy was reinstated in 1988 because it would be too difficult to make meaningful comparisons between the U.S. and Brazilian systems while Brazil was under a nondemocratic regime. ${ }^{58}$

Justices, Presidents, and Senators: A History of the U.S. Supreme Court ApPOINTMENTS FROM WASHINGTON to CLINTON (1999). For severe criticism, see JoHN A. Maltese, The Selling of Supreme Court Nominees (1995).

58. See Lemos \& Llanos, supra note 18, for a political interpretation of each confirmation vote. 
Table Two: Appointments to the Brazilian Supreme Court SINCE THE 1988 CONSTITUTION 59

\begin{tabular}{|c|c|c|c|}
\hline Justice & $\begin{array}{c}\text { Year of } \\
\text { Appointment }\end{array}$ & $\begin{array}{c}\text { Year of Retirement/ } \\
\text { Expected Year of } \\
\text { Retirement }\end{array}$ & President \\
\hline Paulo Brossard & 1989 & 1994 & José Sarney \\
\hline $\begin{array}{l}\text { Sepúlveda } \\
\text { Pertence }\end{array}$ & $\begin{array}{c}1989 \\
\text { [Chief Justice } \\
\text { 1995-1997] } \\
\end{array}$ & 2007 & José Sarney \\
\hline Celso de Mello & $\begin{array}{c}1989 \\
\text { [Chief Justice } \\
\text { 1997-1999] } \\
\end{array}$ & 2015 & José Sarney \\
\hline Carlos Velloso & $\begin{array}{c}1990 \\
\text { [Chief Justice } \\
\text { 1999-2001] }\end{array}$ & 2006 & $\begin{array}{l}\text { Fernando } \\
\text { Collor }\end{array}$ \\
\hline $\begin{array}{l}\text { Marco Aurélio } \\
\text { Mello }\end{array}$ & $\begin{array}{c}1990 \\
\text { [Chief Justice } \\
\text { 2001-2003] }\end{array}$ & 2016 & $\begin{array}{l}\text { Fernando } \\
\text { Collor }\end{array}$ \\
\hline nlmar Galvão & 1991 & 2003 & $\begin{array}{c}\text { Fernando } \\
\text { Collor }\end{array}$ \\
\hline Francisco Rezek & 1992 & 1997 & $\begin{array}{c}\text { Fernando } \\
\text { Collor }\end{array}$ \\
\hline $\begin{array}{c}\text { Maurício } \\
\text { Corrêa }\end{array}$ & $\begin{array}{c}1994 \\
\text { [Chief Justice } \\
\text { 2003-2004] }\end{array}$ & 2004 & $\begin{array}{l}\text { Itamar } \\
\text { Franco }\end{array}$ \\
\hline Nelson Jobim & $\begin{array}{c}1997 \\
\text { [Chief Justice } \\
\text { 2004-2006] }\end{array}$ & 2006 & $\begin{array}{l}\text { Fernando } \\
\text { Henrique } \\
\text { Cardoso }\end{array}$ \\
\hline Ellen Gracie & $\begin{array}{c}2000 \\
\text { [Chief Justice } \\
\text { 2006-2008] }\end{array}$ & 2018 & $\begin{array}{c}\text { Fernando } \\
\text { Henrique } \\
\text { Cardoso } \\
\end{array}$ \\
\hline Gilmar Mendes & $\begin{array}{c}2002 \\
\text { [Chief Justice } \\
\text { 2008-2010] }\end{array}$ & 2025 & $\begin{array}{c}\text { Fernando } \\
\text { Henrique } \\
\text { Cardoso } \\
\end{array}$ \\
\hline Cezar Peluso & $\begin{array}{c}2003 \\
\text { [Chief Justice } \\
\text { 2010-2012] } \\
\end{array}$ & 2012 & $\begin{array}{l}\text { Luis Inácio } \\
\text { Lula da Silva }\end{array}$ \\
\hline $\begin{array}{c}\text { Carlos Ayres } \\
\text { Britto } \\
\end{array}$ & 2003 & 2012 & $\begin{array}{l}\text { Luis Inácio } \\
\text { Lula da Silva } \\
\end{array}$ \\
\hline $\begin{array}{l}\text { Joaquim } \\
\text { Barbosa } \\
\end{array}$ & 2003 & 2024 & $\begin{array}{l}\text { Luis Inácio } \\
\text { Lula da Silva }\end{array}$ \\
\hline Eros Grau & 2004 & 2010 & $\begin{array}{l}\text { Luis Inácio } \\
\text { Lula da Silva } \\
\end{array}$ \\
\hline $\begin{array}{c}\text { Ricardo } \\
\text { Lewandowski }\end{array}$ & 2006 & 2018 & $\begin{array}{c}\text { Luis Inácio } \\
\text { Lula da Silva } \\
\end{array}$ \\
\hline Cármen Lúcia & 2006 & 2024 & $\begin{array}{c}\text { Luis Inácio } \\
\text { Lula da Silva }\end{array}$ \\
\hline Menezes Direito & 2007 & $\begin{array}{c}\text { Deceased } \\
\text { (September 1, } \\
\text { 2009) } \\
\end{array}$ & $\begin{array}{l}\text { Luis Inácio } \\
\text { Lula da Silva }\end{array}$ \\
\hline Dias Toffoli & 2009 & 2037 & $\begin{array}{l}\text { Luis Inácio } \\
\text { Lula da Silva }\end{array}$ \\
\hline Luiz Fux & 2011 & 2023 & $\begin{array}{c}\text { Dima } \\
\text { Roussef }\end{array}$ \\
\hline
\end{tabular}

59. For a detailed list of judicial appointments to the Court before 1988, see http:// www.stf.jus.br/arquivo/cms/sobreStfComposicaoMinistroApresentacao/anexo/Linha sucessoria_tabela_1_9_09.pdf (last visited Apr. 11, 2010). 


\section{A Search for Explanations}

At first glance, a general explanation could simply be that the Brazilian Senate may not play the active role the U.S. Senate plays in shaping policies across different areas. There have indeed been periods in Brazilian history where such attitude prevailed (such as the 1930-1934 and 1937-1946). However, with the 1988 Constitution, the Brazilian Senate became a strong political player. For instance, the Senate Committee on External Relations and National Defense (Comissão de Relações Exteriores e Defesa Nacional) has recently blocked the public hearings of the Presidential nominations of thirteen new Ambassadors in response to Brazilian foreign policy under the Lula administration, in particular, Brazil's stance on Cuban dissidents and nuclear sanctions against Iran. ${ }^{60}$ While strong and interventionist in other areas, it is clear that the Brazilian Senate has not followed the American approach to judicial confirmations during most of the twentieth century. As mentioned earlier, in 121 years of Brazil's republican government (from 1889 to 2010) the Brazilian Senate rejected only five presidential nominees to the Supreme Court, ${ }^{61}$ while in 221 years of independent government in the United States the U.S. Senate declined twelve presidential nominees (from 1789 to 2010). Yet, at least in the last twenty years, the reason why the Brazilian Senate did not adopt the role played by the U.S. Senate in judicial confirmations does not seem related to lack of power to do so.

The development of a different use of power is even more surprising when we acknowledge the similarities of some of the formal details. The Senate Committee on Constitution, Justice and Citizenship (Comissão de Constituição, Justiça e Cidadania) dominates the Brazilian confirmation process. This committee hears the candidates and then makes a recommendation to the full Senate (such recommendation is made by the twenty-three senatorial members of the Committee). In the United States, the Senate Judiciary Committee plays an identically active role. The questioning of presidential nomi-

60. See PSDB declara ruptura com política externa brasileira. Azeredo suspende sabatinas de embaixadores [PSDB declares its rupture with Brazilian external policy. Azeredo suspends public hearings of ambassadors], press release of the Senate Press Agency (Agência Senado), Mar. 16, 2010, available at http://www.senado.gov.br/ Agencia/verNoticia.aspx?codNoticia=100121\&codAplicativo=2 (last visited Apr. 13, 2010). See also Azeredo wants a "more active" Senate in the debate on foreign policy, press release of the Senate Press Agency International (Agência Senado International), Apr. 9, 2010, available at http:/www.senado.gov.br/Agencia/internacional/en/ not_1007.aspx.

61. See De Mello Filho, supra note 36 , at 17. 
nees began in 1939 with the confirmation of Justice Felix Frankfurter. ${ }^{62}$

Another similarity is the role played by the local bar organizations. As we have seen before, the Brazilian Bar Association (Ordem dos Advogados do Brasil) has a significant role in the process of judicial appointments by the President to the appellate and superior courts (with the exception of the Supreme Court).

In the United States, the American Bar Association has played an informal role in the nomination and confirmation process since the late 1940s. ${ }^{63}$ President George W. Bush decided to eliminate the role of the $\mathrm{ABA}$ as an informal gatekeeper, due to his perception that the organization had a liberal bias. Conflicts between the Brazilian Bar Association and other institutional actors in the appointment process have also occurred. Recently, these conflicts emerged between the Brazilian Bar Association and the judiciary itself (but not between the Brazilian Bar Association and the President). In 2008, the Superior Court of Justice decided to reject all six of the candidates that the Brazilian Bar Association suggested ${ }^{64}$ (as explained earlier, the $\mathrm{Su}$ perior Court of Justice selects three candidates out of a pool of six, and the President ultimately selects one). The Supreme Court upheld that decision in October 2009 by denying the Brazilian Bar Association's appeal. ${ }^{65}$ The Brazilian Bar Association eventually provided a new list for the vacant seat in $2010 .{ }^{66}$

In our opinion, one cannot simply attribute the largely deferential behavior of the Brazilian Senate to the President's appointments to the Supreme Court to a mere path dependence, either. A military dictatorship (1964-1985) and a largely negotiated political transition

62. See Abrahams, supra note 57. Felix Frankfurter was an Associate Justice of the United States Supreme Court from January 1939 to August 1962. He was nominated by President Roosevelt and confirmed by the Senate without dissent.

63. Since 1946, the ABA has established a Standing Committee on Federal Judiciary in an advisory role on the selection of, among others, Supreme Court Justices. After a candidate is nominated, the ABA Committee investigates the merits and rates the nominee according to "well qualified," "not opposed," or "not qualified." These advisory ratings tend to have great sway on the Senate Judiciary Committee and on the Senate. Details available at http://www.abanet.org/scfedjud/SCpage/fjcscprocess.pdf (last visited Apr. 11, 2010).

64. See STJ veta lista de indicações da OAB e abre crise [SCJ vetoes the list of appointments by the BBA, and causes a crisis], Feb. 14, 2008, http://www.estadao. com.br/noticias/nacional,stj-veta-lista-de-indicacoes-da-oab-e-abre-crise, 124445,0.htm (last visited Sept. 27, 2010).

65. See Mantida decisão do STJ de rejeitar lista sêxtupla da OAB para escolha de ministro daquela corte [Upholding the decision of the STJ to reject the OAB's sextuple list to select a judge of that court], Brazilian Supreme Court press release, Oct. 6, 2009, available at $\mathrm{http}: / / \mathrm{www}$.stf.jus.br/portal/cms/verNoticiaDetalhe.asp?idConteudo $=114297 \&$ caixaBusca $=$.

66. See OAB preencherá vagas no STJ [BBA will fill vacancies at SCJ, Federal Justice at the State of Rondônia press release on Aug. 10, 2010, available at http:// www.ro.trf1.gov.br/noticias/2010/OAB\%20preencher\%E1\%20vagas\%20no\%20STJ. htm. 
(1985-1988) certainly reinforced a strong presidential tradition and hurt the establishment of an equally strong legislature. Still, given the political importance of the Brazilian Congress since the late 1980 s, one cannot observe a path dependence in other political contexts.

\section{Same Transplant, Different Outcomes: Looking at the United States}

A detailed look at the case of the United States suggests reasons why the Brazilian Senate has not adopted a more contentious approach to Supreme Court confirmations. By the time Brazil adopted the U.S. model in the late nineteenth century, the importance of the Supreme Court and the role of the Senate as a limit to presidential choices was firmly established in the United States. The process of senatorial confirmation had produced several clashes between presidents and senators by the $1890 \mathrm{~s}$. At that time the process in the United States was essentially about particular partisan agendas and a means to express opposition to any presidential actions that the Senate did not like. The switch in the United States from punishing the President for occasional disagreements to a recurrent ideological rejections of nominees occurred in the twentieth century and was strongly entrenched by the twenty-first. ${ }^{67}$

At the same time, for other federal judicial appointments in the United States, a presumption of senatorial courtesy was in place by the 1890s: the nominee should be agreed upon by both the President and the Senator from the home state. The presumption of senatorial courtesy established a guarantee that judicial appointments for district and appellate courts were generally less contentious. This presumption of senatorial courtesy declined for most of the twentieth century, and was replaced in the 1970 s by the same ideological divisions that taint the Supreme Court appointments. At best, senatorial courtesy has been replaced by courtesy to the President's party. ${ }^{68}$

The dynamics of judicial appointments in the United States reflect the political importance of its judiciary. Whatever the intentions were at the Constitutional Convention, the U.S. Supreme Court emerged as a political actor of fundamental importance, as a product of Jeffersonian anger in the early 1800s and of Jacksonian defiance in the $1820 \mathrm{~s} .{ }^{69}$ From then on, the U.S. Supreme Court, in an effort to achieve judicial supremacy, constantly sought to broaden its power. The initial deference of the Court toward Congress eroded over time and major crises occurred during the 1930s and in the late twentieth

67. See Gardner GeYh, supra note 52 .

68. Id.

69. Id. 
century. ${ }^{70}$ The political authority of the Supreme Court was based on case law that reflects the cyclical rise and fall of judicial activism.

One cannot say that the U.S. Supreme Court has achieved its current political role and influence solely by judicial construction. The other two branches of government, as well as the states, presumably could have undermined such a construction if they felt the need to do so. Apart from well-known skirmishes, such as during the New Deal in 1937, there has been little use of impeachment procedures, the possibility of court packing, constitutional amendments or other mechanisms to limit the power of the Supreme Court. ${ }^{71}$ One has to conclude that the various political actors have allowed the emergence of a politically strong Supreme Court because it is in their interest. ${ }^{72}$

The U.S. Supreme Court has emerged as a strong referee between the federal government and the states. States naturally favored such a development to avoid the control of the federal government by particular (larger or wealthier) states and, more importantly, to protect extensive state powers. As the bipartisan political system was established by the late nineteenth century, both parties were inclined to accept the strong role of the federal judiciary and the Supreme Court, mainly as a mechanism to limit the influence of the party that currently controlled Congress and to avoid sidelining the party in opposition. The fact that no party has controlled the political establishment of the United States for a long period of time has allowed the judiciary to emerge as a politically powerful branch. Thus, the influence and power of the U.S. Supreme Court are the result of a combination of specific interests competing in the public sphere. ${ }^{73}$

Because of its politically strong position, the U.S. Supreme Court attracts attention from many different political actors. It is not surprising, therefore, that the process of nomination and confirmation has become more contentious. The President and the Senate view the Supreme Court's role as the shaper of policies and legacies for the future. For example, the U.S. Supreme Court constrains the constitutional agenda of future presidential terms. ${ }^{74}$ The political repercussions that stem from a single judicial appointment have become glaringly obvious and have made the ideology behind a selection very important. ${ }^{75}$ The behavior of the Supreme Court justices seems

70. $I d$.

71. Id.

72. See Keith E. Whittington, Political Foundations of Judicial Supremacy: The Presidency, the Supreme Court, and Constitutional Leadership in U. S. HisTORY (2007).

73. See William Landes \& Richard A. Posner, The Independent Judiciary in an Interest-Group Perspective, 18 J. L. EcoN. 875 (1975).

74. See GreEnBURG, supra note 56.

75. The polarization of Congress has generated more negotiated legislation that ex post invites the intervention of the courts. Unlike other common law jurisdictions, 
to support such a view given the their adherence to what has been called by political scientists the attitudinal model. ${ }^{76}$

The prevalence of precedent and the respect that the U.S. Supreme Court commands from other federal and state courts reinforces the view that judicial selection for the highest bench of the country is bound to raise political expectations and serious ideological concerns. ${ }^{77}$

\section{E. Same Transplant, Different Outcomes: Looking at Brazil}

The importance of the U.S. Supreme Court, as well as the strong political role of the U.S. Senate in judicial appointments, was well established by the early 1890 s. Consequently, when the U.S. system was transplanted to Brazil it was expected that Brazil would also embrace an active Senate. As history has shown, that was indeed the case in the early days but then changed over the last century.

Before 1988, it is hard to make a direct comparison between the U.S. and the Brazilian Senate given the different political regimes. ${ }^{78}$ However, once democracy was reestablished in 1988, the Brazilian Senate emerged as an active political body in many political areas, including constitutional amendments. ${ }^{79}$ Public hearings, now broadcasted live on television, made the confirmation process of judicial nominations accessible to all Brazilian citizens as well as strenuous and transparent. However, the deferential attitude concerning the President's judicial nominations remained unchanged.

There are three possible reasons why the Brazilian Senate did not adopt a contentiously active role.

The composition of the Brazilian Supreme Court does not display the ideological configuration that is present on the U.S. Supreme Court. The Brazilian Supreme Court has less ideological and party tensions surrounding their appointments. Because of the career judiciary's predominance in other courts, the majority of Brazilian justices nominated after 1988 are detached from the career judici-

in many cases, ex ante political intervention and discussion by the U.S. Congress has been replaced by ex post judicial intervention. The growing need for more statutory interpretation has further politicized the federal judiciary. See generally JuDICIAL ACTIVISM IN Common Law SuPREme CourTs (Brice Dickson ed., 2007).

76. See Jefrrey A. Segal \& Harold J. Spaeth, The Supreme Court and the AtTitudinal Model Revisited (2002).

77. See Thomas G. Hansford \& James F. Spriggs II, The Politics of Precedent ON THE U.S. SUPREME COURT (2006).

78. For a detailed discussion of the impact of democracy on the appointment and confirmation processes in Brazil, see Mariana Prado \& Claudia Türner, A Democracia e o seu Impacto nas Nomeações dos Diretores das Agências Reguladoras e Ministros do STF [Democracy and its Impact on the Nominations of Directors of Regulatory Agencies and Justices of the FSC], 250 REVISTA DE Direito AdMINISTRATIVo 27 (2009).

79. There have been sixty-four constitutional amendments since 1988, some of them reshaping the judiciary, such as Emenda Constitucional number 45, December 2004. 
ary. ${ }^{80}$ The influence of the civil law tradition has also contributed to the development of a particular type of legal formalism (in particular, deference to the legislator) that contrasts with the contentious political activism that surrounds the U.S. Supreme Court. ${ }^{81}$ As a result, the clashes between ideological majority and minority that are frequent on the U.S. Supreme Court are rare in Brazil. ${ }^{82}$ Such clashes do occur, but they involve particular issues and the line-up in the Court is fairly independent from previously defined ideological tendencies or coalitions. Yet the Brazilian Supreme Court is decidedly activist in highly relevant areas, ${ }^{83}$ particularly its competence regarding abstract judicial review. In fact, legal scholars have recognized the activism of the Court in areas of social legislation, creation and development of new rights, and access to justice. ${ }^{84}$ For example, the Court has struck down the law regulating the press (Lei da Imprensa), which had been in force since 1967. In recent times, the Court has also heard cases involving stem cells, complaints against the public health care system, and affirmative action in public universities.

Unlike its U.S.-American counterpart, the Brazilian Supreme Court has historically had little control over its docket because it does not have a writ of certiorari. It is true that there is now a new requirement of "general interest for admission of extraordinary appeals": if an appeal does not achieve the status of general interest or general repercussion, review is immediately declined by the Court. This requirement, in place only since 2007 , is expected to reduce the workload and allow the Court to focus on more important cases. ${ }^{85}$

80. Of the nineteen justices appointed since 1988 (see Table two), only four were previously career judges. If we include judges who served at appellate or superior courts by appointment under the quinto constitutional as explained before (they have judicial experience but are not technically career magistrates), the number goes up to seven, thus thirty-seven percent of the sample.

81. See Nuno Garoupa \& Maria Alejandra Maldonado, The Judiciary in Political Transitions: The Critical Role of U.S. Constitutionalism in Latin America, CARDOZo J. INT'L \& CoMP. L. (forthcoming 2011).

82. Unfortunately, there are few empirical studies about the attitudinal model in Brazil, but the existing literature shows a pattern of less polarized division than in the United States. See discussion by Garoupa \& Maldonado, id.

83. For a discussion of the behavior of the Supreme Court from a political and economic perspective, see Lee J. Alston, Marcus Melo, Bernardo Mueller \& Carlos Pereira, On the Road to Good Governance: Recovering from Economic and Political Shocks in Brazil, in Policymaking in Latin America: How Politics Shapes Policies (Ernesto Stein, Mariano Tommasi, Carlos Scartascini, \& Pablo Spiller eds., 2008).

84. See Rogério B. Arantes, Constitutionalism, the Expansion of Justice and the Judicialization of Politics in Brazil, in The Judiclalization of Politics In Latin AMERICA (Rachel Sieder, Line Schjolden \& Alan Angell eds., 2005). He sees two main reasons for the increasing activism of the Court: (i) The constitutionalization of welfare rights preventing rights and principles from being altered after new elections, and (ii) the length of the 1988 Constitution and the profusion of amendments which has empowered the Court.

85. The Emenda Constitucional number 45, December 2004, introduced a mechanism that could in principle approximate the writ of certiorari under the name of a 
Still, the Court's historical inability to select cases has affected its activism only insignificantly. The main difference, in our view, is that the level and scope of activism is less partisan-oriented in Brazil than in the United States.

Finally, the absence of a general principle of stare decisis and strong precedent has reduced the Supreme Court's power to bind the lower courts in the past. ${ }^{86}$ This absence is in line with the civil law tradition although it has recently been tempered by the new sumula vinculante. ${ }^{87}$ In fact, the main criticism regarding the new sumula vinculante system is that it empowers the Brazilian Supreme Court and reduces heterogeneity across courts, therefore arguably impairing the independence of the lower tribunals. ${ }^{88}$ For all these institutional reasons, the composition of the Brazilian Supreme Court has not attracted the ideologically partisan attention to make the Senate confirmation more controversial.

As discussed before, the emergence of the political importance of the U.S. Supreme Court is in part derived from the balance of power between the federal and state governments. In Brazil, the states have limited power and the resulting influence of the federal government is overwhelming. ${ }^{89}$ American federalism was the result of transfer of sovereignty by each of the thirteen colonies to the center. By contrast,

requirement of general interest (requisito da repercussão geral). Article 102, paragraph 3 of the Brazilian Constitution has stated since 2004: "In the extraordinary appeal, the appellant shall prove the general repercussion of the constitutional issues discussed in the case, as prescribed by law, in order for the Court to examine the admission of the appeal, the refusal being permitted only by voting of two thirds of the Justices." As a consequence, the implementing Law 11418/2006 limits the court jurisdiction to appeals of general interest or of general impact (social, economic, political or legal). It has been applied since 2007 and has raised significant legal issues that are beyond the scope of the present Article.

86. Before the existence of súmula vinculante, courts could apply different legal reasoning than that of the Supreme Court. Even when courts followed the Supreme Court decisions, this previous system did not bar appeals, hence allowing excessive and inefficient appeals, such as strategic appeals with the sole purpose of postponing the enforcement of an unfavorable judgment. For a discussion about the search for judicial supremacy in Brazil, see Diego Werneck Arguelhes, $O$ Supremo na Política: $a$ Construção da Supremacia Judicial no Brasil, [The Supreme Court in Politics: The Construction of Judicial Supremacy in Brazil] 250 REvista DE DiReito ADMINISTRATrvo 5 (2009).

87. Introduced by the Emenda Constitucional number 45, December 2004, the súmula vinculante is a one-sentence-pronouncement issued by the Brazilian Supreme Court, with binding effect on all other courts, which states clearly the interpretation the Brazilian Supreme Court gave to a constitutional issue. For instance, súmula vinculante $n .12$ reads: "Charging enrollment fees to students in public universities violates article 206, IV, of the Federal Constitution." At the date of writing this Article, the Brazilian Supreme Court has issued thirty-one súmulas vinculantes. For more details on the sumula vinculante, see Oliveira, supra note 14.

88. Arantes, supra note 84 , suggests that the new súmula vinculante has been criticized and badly received by the sectors that want to use the courts strategically for political goals or to avoid expensive claims.

89. See Charles D. Cole, Comparative Constitutional law: Brazil and the UNITED STATES (2d ed. 2008). 
Brazilian federalism, more familiar to British devolution, derives from the central government's delegation of powers to the states. Moreover, Brazil's governmental system includes three actors: the federation, the state, and the municipalities. ${ }^{90}$ Quite simply, the federal government in Brazil has considerably more power over the states than the U.S. federal government. As explained, the Brazilian Supreme Court can broadly review state laws and state courts' decisions. ${ }^{91}$ Consequently, the Brazilian Supreme Court's role in actively refereeing conflicts between the federal government and the states is not nearly as strong as in the United States. Instead, the Brazilian Supreme Court is the paramount referee in conflicts of federalism and separation of powers within the state and federal spheres of government (e.g., the state legislature/governor conflicts, congress minorities/president conflicts)..$^{92}$ Although these conflicts are politically relevant, due to the large number and instability of political parties, they do not result in a partisan division of the Court.

Finally, unlike the United States, Brazil does not have a stable two-party system. Since democracy was consolidated in 1988, a multitude of parties have emerged. Currently, more than ten political parties have at least one senator in a Senate of eighty-one. As a result, the Brazilian Senate is neither polarized nor structured around two stable coalitions. Instead it moves in conjunction with the needs of a presidential majority. At the same time, there are no clear alternations of political cycles. Some parties frequently move in and out of the presidential majority. Therefore, it is much easier for the President to rally support for his nominees than it is for a diffuse, divided, and heterogeneous opposition to undermine or block confirmation. Additionally, the fragmentation of the party system supports the building of the needed consensus out of the public eye instead of utilizing specialized public committee meetings or the plenary of the Senate.

90. Id.

91. Id. (so can the United States Supreme Court though only with regard to compliance with the federal Constitution and other federal law).

92. The judicialization of political questions has become a relevant phenomenon in the Supreme Court due to its power to review the constitutionality of federal and state laws in abstract. It is fairly common that a losing minority in Congress requests the Supreme Court to review the constitutionality of a newly-enacted law which they opposed, but did not succeed in blocking, in Congress. For more detailed information on minority parties/President conflicts before the judiciary, see Matthew M. Taylor, Working the Courts: The Worker's Party and the Judicialization of Politics in Brazil (paper presented at the annual meeting of the American Political Science Association), available at $\mathrm{http} / / \mathrm{www}$.allacademic.com/meta/p61115_index.html. For state legislature-governor conflicts refereed by the Supreme Court, see Iran Rodrigues, Judicialization of Politics: Constitutional Review and Intrastate Litigiousness in Contemporary Brazil (paper presented at the annual meeting of the Southern Political Science Association) (2009), available at http://www.allacademic.com/meta/p275709_ index.html. 
Still, the distinctive evolution of the U.S. transplant in Brazil also achieves a particular balance of power between the elected political actors (the President and Congress) and the non-elected ones (the judiciary). We believe that the existence of a career judiciary and the limited powers of the President when it comes to appointments of recognition judiciary to the Superior Courts provide another explanation for the largely deferential approach taken by the Brazilian Senate.

In a sense, a deferential Senate compensates the President for the limited powers he has in shaping the Brazilian judiciary. By contrast, in the United States the President has enormous influence in shaping the federal judiciary. A less deferential Senate is thus needed to introduce some checks and balances into the U.S. federal system of judicial selection.

In fact, by enhancing the presidential powers, a deferential Brazilian Senate contributes to a more effective system of checks and balances between the federal government and the career judiciary. In the United States, a deferential Senate in an institutional environment without a career judiciary would likely result in overwhelming power of the President over the entire federal judiciary. In Brazil, by contrast, continuous conflicts between the President and the Senate over appointments to the Supreme Court would likely enhance the position of the career judiciary because of the weak Presidential influence over the federal appellate courts and superior courts.

\section{Conclusion}

This Article discussed the current system of judicial selection in Brazil and how it compares to the U.S. model. For entry level judges in Brazil, the standard civil law shortcoming is observed, namely that career judges are hired at a very young age. However, we can also find the standard advantage of a career judiciary, that is, significant insulation from political pressure.

This Article also discussed the legal transplant of the U.S. system of judicial appointments to the Supreme Court to Brazil and noted that this transplant did not result in a contentious Brazilian Senate confirmation process. We proposed a multitude of explanations that rely on local determinants, particularly the lack of a clearcut bipartisan ideology of the Court, the party system, the particularities of Brazilian federalism, and the balance between career and recognition judiciaries.

We must emphasize that the Article is completely agnostic as to which institutional developments (United States or Brazil) are more adequate or which approach adopted by the respective Senates results in a more qualified judiciary. Our purpose was to recognize and explain why similar constitutional rules have evolved into different practices. In no way does this Article suggest that a particular prac- 
tice is better or worse than another. It seems that both practices accommodate the local institutional needs to balance the various political powers involved. 


\begin{tabular}{|c|c|c|c|c|c|c|c|c|c|c|c|}
\hline 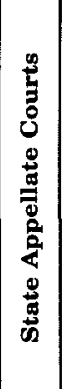 & 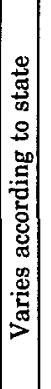 & 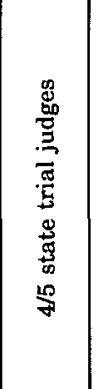 & 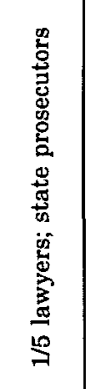 & 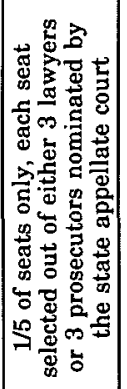 & 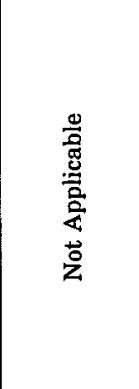 & 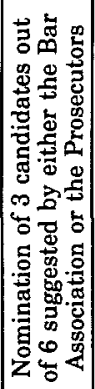 & 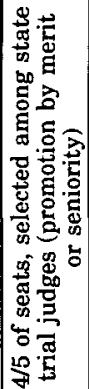 & 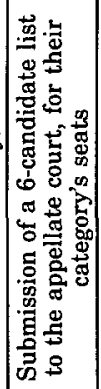 & 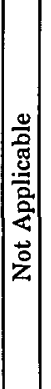 & 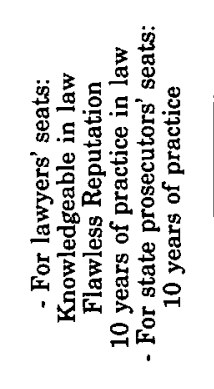 & 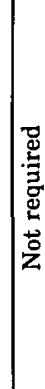 \\
\hline 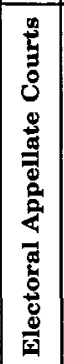 & - & 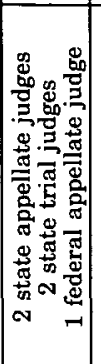 & 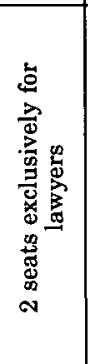 & 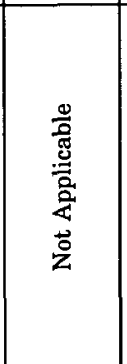 & 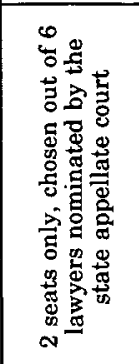 & 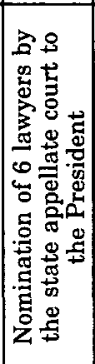 & 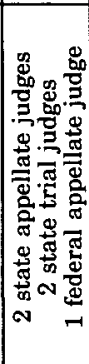 & 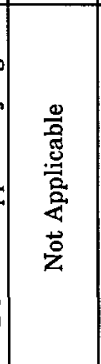 & 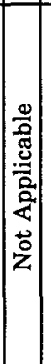 & 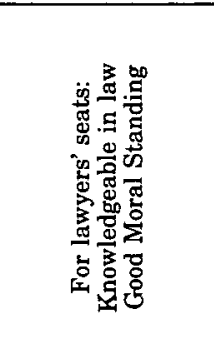 & 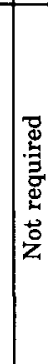 \\
\hline 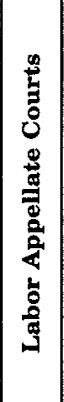 & 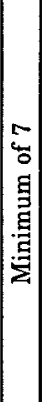 & 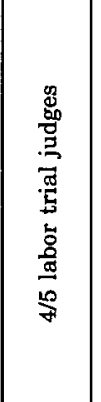 & 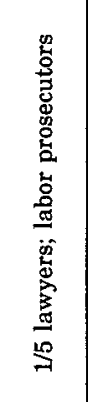 & 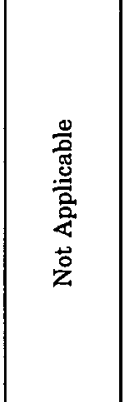 & 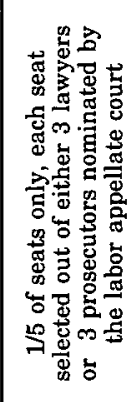 & 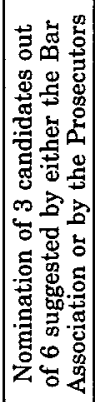 & 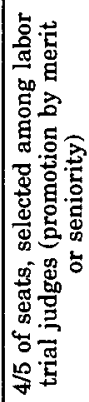 & 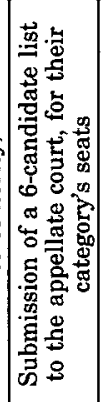 & 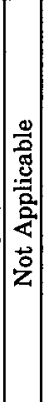 & 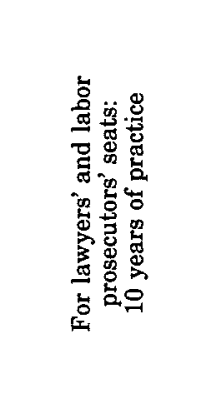 & 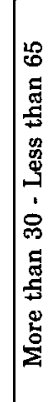 \\
\hline 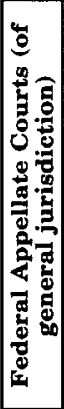 & 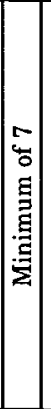 & 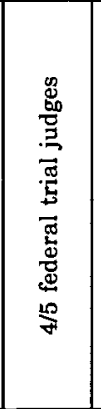 & 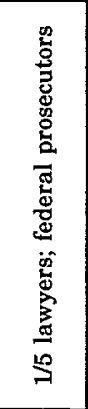 & 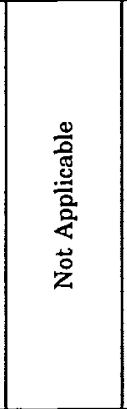 & 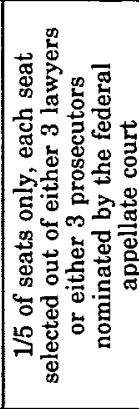 & 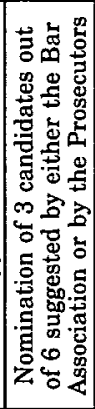 & 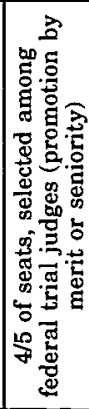 & 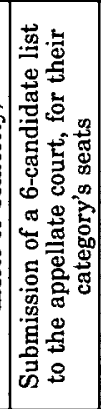 & 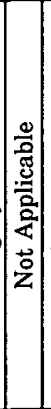 & 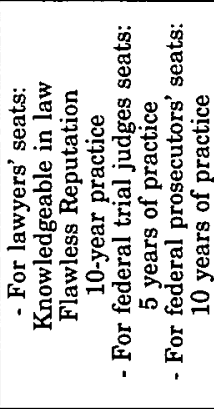 & 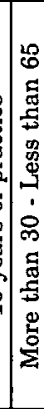 \\
\hline & 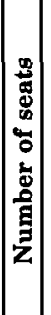 & 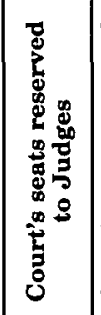 & 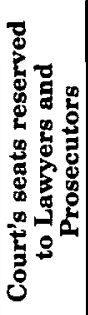 & 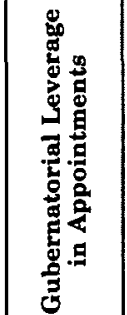 & 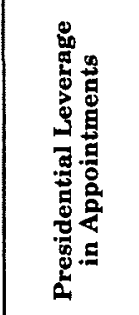 & 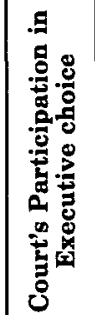 & 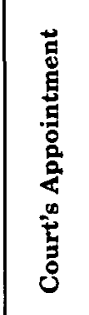 & 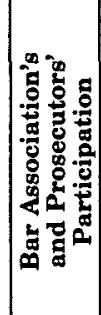 & $\mid$ & 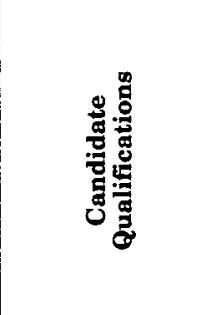 & 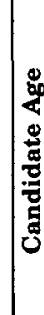 \\
\hline
\end{tabular}




\begin{tabular}{|c|c|c|c|c|c|c|c|c|c|c|c|}
\hline 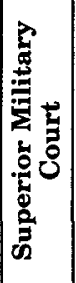 & 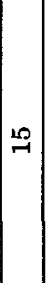 & 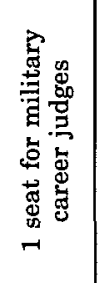 & 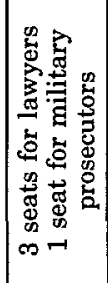 & 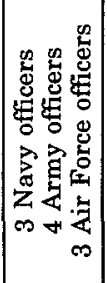 & 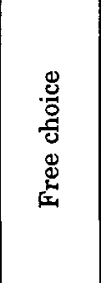 & 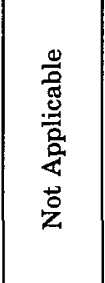 & 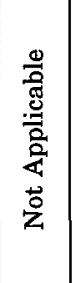 & 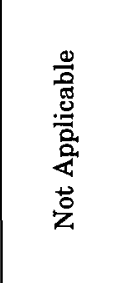 & 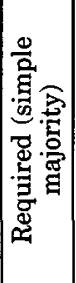 & 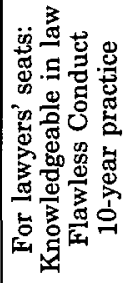 & 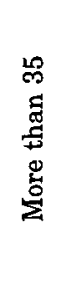 \\
\hline 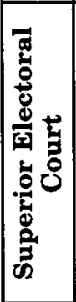 & - & 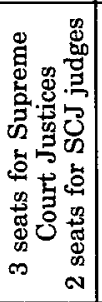 & 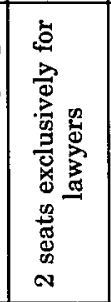 & 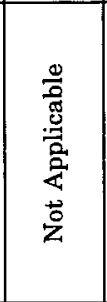 & 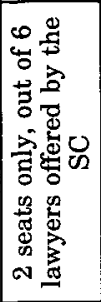 & 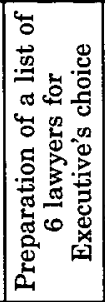 & 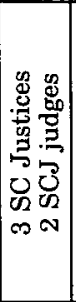 & 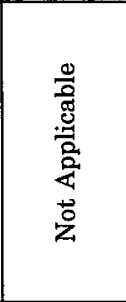 & 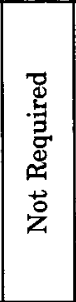 & 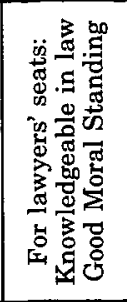 & 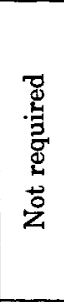 \\
\hline 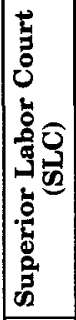 & $\hat{\approx}$ & 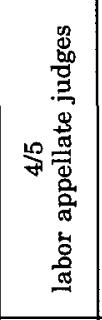 & 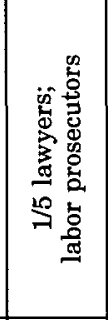 & 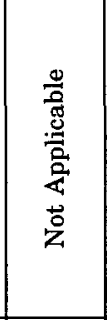 & 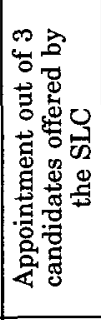 & 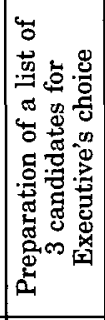 & 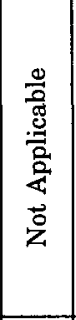 & 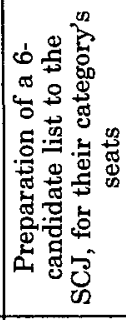 & 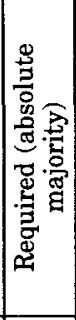 & 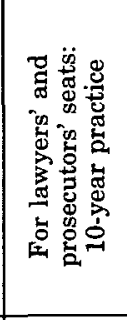 & 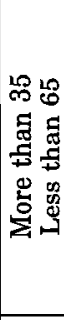 \\
\hline 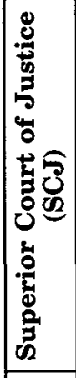 & $\mathscr{m}$ & 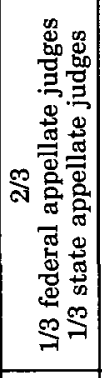 & 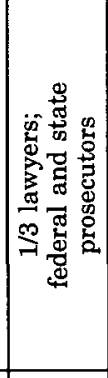 & 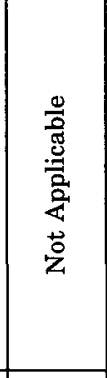 & 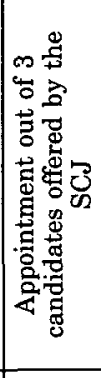 & 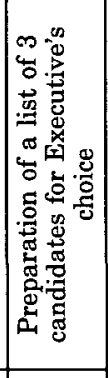 & 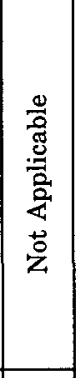 & 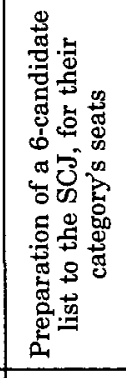 & 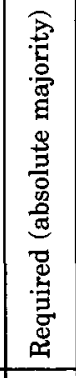 & 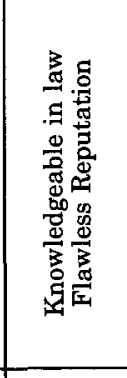 & 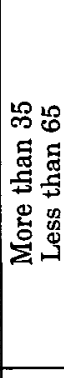 \\
\hline 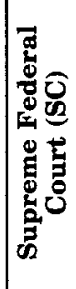 & $\exists$ & 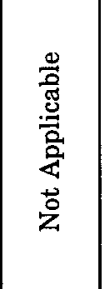 & 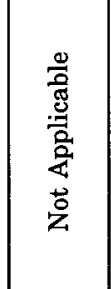 & 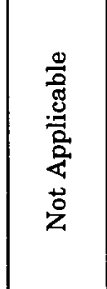 & 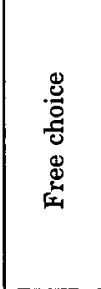 & 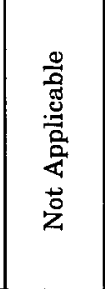 & 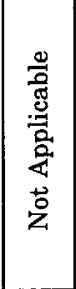 & 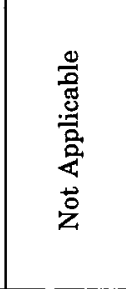 & 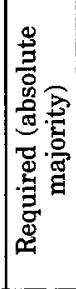 & 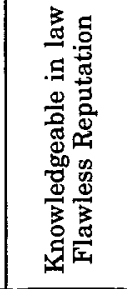 & 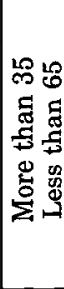 \\
\hline & 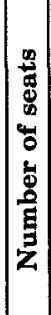 & 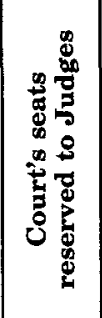 & 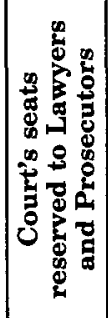 & 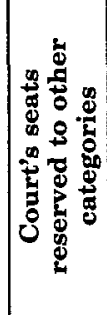 & 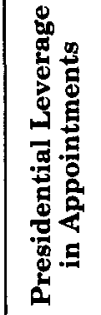 & 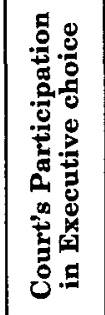 & 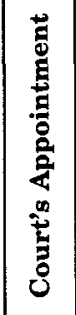 & 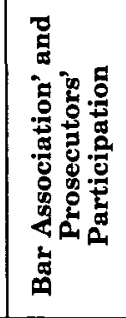 & 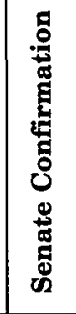 & 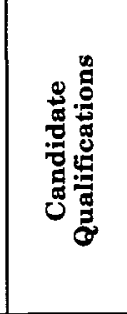 & 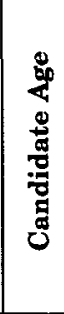 \\
\hline
\end{tabular}


